\title{
Genotypical characterization of thermotolerant coliforms isolated from food produced by a Solidarity Economic Venture of Bahia (Brazil)
}

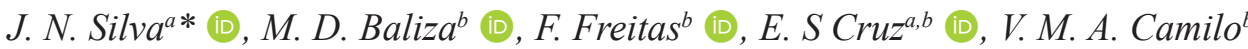 \\ and I. M. M. Silva ${ }^{a, b}$
}

aPrograma de Pós-graduação em Microbiologia Agrícola, Centro de Ciências Agrárias, Ambientais e Biológicas, Universidade Federal do Recôncavo da Bahia (UFRB), Rua Rui Barbosa, 710, Centro, CEP 44380-000, Cruz das Almas, BA, Brasil

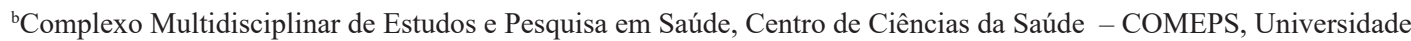
Federal do Recôncavo da Bahia (UFRB), Avenida Carlos Amaral, R. do Cajueiro, 1015, CEP 44570-000, Santo Antônio de Jesus, BA, Brasil

*e-mail: jaialanascimento@gmail.com
\end{abstract}

Received: July 31, 2019 - Accepted: October 4, 2019 - Distributed: February 28, 2021

(With 2 figures)

\begin{abstract}
Many Solidarity Economic Venture (SEV) are family farmers who seek to add value to production through artisanal processing, which can lead to food contamination. Thus, this study aimed to genotypically characterize thermotolerant coliforms (TtC) strains from food produced by local agribusinesses of SEV during January to April 2019. Samples from thirteen production units (PU) from the SEV were submitted to a microbiological analysis of thermotolerant coliforms (AFNOR 3M1/2 - 09/89), using a fast count method in Petrifilm ${ }^{\mathrm{TM}}$ dishes. The Polymerase Chain Reaction (PCR) technique was used to verify the following virulence genes (VGs) associated with Escherichia coli: stx, typical from enterohemorrhagic E. coli (EHEC); bfpA typical from entheropathogenic E. coli (EPEC) and elt and slt, typical from entherotoxigenic E. coli (ETEC). The results showed that two samples of queijadinha (typical Brazilian candy made with eggs and coconut) and one sample of cassava cake presented characteristic colonies TtC. This way, three strains were isolated in order to perform the PCR technique. However, the genes used in the reaction were not detected in the isolated strains. Therefore, it is suggested that the isolated strains are from $E$. coli pathotypes with different virulence genes than the ones analyzed belong other types of $\mathrm{TtC}$, such as Enterobacter and Klebsiella. Although the virulence of genes has not been confirmed, the presence of $\mathrm{TtC}$ on food indicates hygiene flaws during production and, therefore, measurements to control and prevent contamination should be taken.
\end{abstract}

Keywords: Enterobacteriaceae, microbial genetics, polymerase chain reaction, food and nutritional safety, foodborne illness.

\section{Caracterização genotípica de coliformes termotolerantes isolados de alimentos produzidos por um Empreendimento Econômico Solidário}

\begin{abstract}
Resumo
Muitos Empreendimentos Econômicos Solidários (EES) são formados por agricultores familiares que buscam agregar valor à produção por meio do beneficiamento artesanal, que pode ocasionar a contaminação dos alimentos. Desta forma, este estudo objetivou caracterizar genotipicamente coliformes termotolerantes $(\mathrm{CT})$ isolados em alimentos produzidos por agroindústrias de um EES no período de janeiro a abril de 2019. Então, foi realizada análise microbiológica de coliformes termotolerantes (AFNOR 3M1/2 - 09/89), utilizando um método contagem de contagem rápida em placas Petrifilm ${ }^{\mathrm{TM}}$, em amostras de alimentos de treze Unidades de Produção (UP) do EES. Foram coletadas assepticamente cinco amostras de cada UP, totalizando 65 amostras. Utilizou-se a técnica de Reação em Cadeia de Polimerase (PCR) para verificação dos seguintes genes de virulência de Escherichia coli: stx, característico de E. coli enterohemorrágica (EHEC), bfpA, característico de $E$. coli enteropatogênica (EPEC) e elt e $s t I$, característicos de $E$. coli enterotoxigênica (ETEC). Os resultados demonstraram que duas amostras de queijadinha e uma amostra do bolo de aipim apresentaram colônias características de coliformes termotolerantes. Desta forma, foram isoladas três cepas para a realização da PCR, no entanto os genes utilizados nas reações não foram identificados nas cepas isoladas. Portanto, sugere-se que as cepas isoladas sejam de patótipos de $E$. coli com genes de virulência diferentes dos analisados ou de outro membro dos CT, como Enterobacter e Klebsiella. Apesar de não serem confirmados os genes de virulência analisados, a detecção dos CT nos alimentos indica falhas na higiene durante a produção, portanto medidas para controlar e prevenir a contaminação dos produtos devem ser tomadas.
\end{abstract}

Palavras-chave: Enterobacteriaceae, genética microbiana, reação em cadeia da polimerase, segurança alimentar e nutricional, doenças transmitidas por alimentos. 


\section{Introduction}

Solidary Economic Ventures (SEVs) adopt initiatives that favor the generation of new ways of production, labor and income. Its main characteristics are self-management, results sharing and a horizontal structure, in which the entrepreneurs have the autonomy to make their own decisions (Bella et al., 2018). There was an increase in the number of cooperatives in Brazil and agricultural production cooperatives increased from 1,548 in 2010 to 1,613 in 2018 (OCB, 2019). Many of these groups seek to add economic value to their agricultural production through processing. However, many times the processing of the raw materials is made in an artisanal fashion (Ribeiro, 2017; Rodrigues et al., 2015).

Artisanal food processing may be a risk to the occurrence of Foodborne Diseases due to the presence of microorganisms in food, utensils and/or manufacturers. Thus, the adoption of Good Manufacturing Practices during the processing of products is essential (Silva et al., 2017).

Among the etiological agents that cause foodborne illness, Escherichia coli, a bacteria part of a group of microorganisms called thermotolerant coliforms, stands out. It presents the characteristic of fermenting lactose with gas production when incubated at $44.5-45.5{ }^{\circ} \mathrm{C}$. Enterobacter and Klebsiella are genders that are also part of this group of coliforms. However, generally under these conditions around $90 \%$ of the cultures are positive for E. coli, whilst only a few strains of Enterobacter and Klebsiella maintain this characteristic (Macedo et al., 2016). In Brazil, E. coli is amongst the main etiological agents identified in foodborne illness outbreaks (Pombo et al., 2018). The natural habitat of this microorganism is the intestines of humans and other warm-blooded animals. While most strains are harmless, some can cause severe foodborne disease. E. coli infection is usually transmitted through consumption of contaminated water or food, such as undercooked meat products and raw milk. Thus, the presence of $E$. coli in food indicates fecal contamination, probably due to poor hygiene during manipulation and/or use of contaminated water (WHO, 2019)

In addition, there is a growing concern regarding the prevalence of multi-drug resistance in coliforms, as Escherichia coli, which makes antibiotic therapy incompetent (Mishra et al., 2018).

There are six pathogenic $E$. coli pathotypes, collectively known as diarrheagenic E. coli (DEC). They have a predilection for the host's enteral cells, causing intestinal infection and they are classified as: enteropathogenic $E$. coli (EPEC), enterotoxigenic E. coli (ETEC), enteroinvasive E. coli (EIEC), enterohemorrhagic E. coli (EHEC) or Shiga toxin-producing $E$. coli (STEC), enteroaggregative E. coli (EAEC) and diffusely adherent E. coli (DAEC) (Souza et al., 2016). EPEC cause childhood diarrhea and its action mechanism is through the destruction of small intestine microvillus. The main symptoms observed in infections caused by EIEC are high fever and watery diarrhea, that may progress to ulceration of the host's epithelium. The disease known as traveler's diarrhea is caused by ETEC and occurs from the consumption of water or food contaminated with fecal material. EAEC strains cause acute and chronic diarrhea in children. The symptom observed in DAEC infections is watery diarrhea, especially in children between 1 and 5 years old. And finally, EHEC is responsible for causing watery diarrhea, hemorrhagic colitis and hemolytic uremic syndrome (Rosa et al., 2016). The research for $E$. coli in foods reveals safe information about the hygienic and sanitary conditions of the products, as it is an indicative of fecal contamination. Furthermore, these microorganisms have pathogenic strains that can lead to outbreaks of foodborne illness.

Therefore, the investigation of virulence genes in Escherichia coli isolates is necessary to identify pathogenic strains, as was done by Barbosa et al. (2019) in a research carried out with mussel (Mytella guyanensis) commercialized in Cachoeira, Bahia, Brazil, and the elt gene, typical from enterotoxigenic infection, was detected in $75 \%$ of the 24 isolates.

Considering the scarcity of studies involving the research of virulence genes in food isolates from family agriculture and the importance of E. coli as an etiological agent of foodborne illness, the objective of this work was to genotypically characterize the isolates of $\mathrm{TtC}$ from foods produced by farms and processing facilities from a SEV.

\section{Material and Methods}

The venture headquarters was located in Valença (Bahia State, Brazil) and developed as its main economic activity the retail of fresh produce and, as secondary economic activities, the commercial manufacturing of compotes, jams, candy bars, dehydrated fruits, seasonings, cassava flour and its derivatives, biscuits and cookies, cakes, beijus (delicacy based on cassava starch), breads and various savory dumplings.

This study was conducted during the period of January to April 2019. The samples were aseptically collected from all production units that benefited food, totaling 13 units, involving 52 family farms. Due to the great diversity of food produced, it was decided to collect and analyze the bestselling product of each production unit. Five sample of each food were collected, corresponding to the batch, and totaling 65 samples, which were collected in their commercial packaging in the production unit. The samples were transported refrigerated in an isothermal container and sent to the Multidisciplinary Health Studies and Research Complex of the Federal University of Recôncavo da Bahia (UFRB) in Santo Antônio de Jesus, Bahia State, Brazil, where the microbiological analysis of the product samples was immediately performed.

The selected products were: banana biscuit, cocoa jam, queijadinha (candy based of eggs and coconut), gluten-free cassava biscuit, beiju, chicken seasoning, coconut biscuit, banana chips, sugar-free banana candy bar, jenipapo (edible berry from the Genipa americana tree) candy, cassava cake, cocoa cocada (treat based of 
coconut) and puba (fermented cassava) cake wrapped in banana leaves.

The quantification of thermotolerant coliforms (AFNOR $3 \mathrm{M} 1 / 2$ - 09/89) was achieved through Petrifilm ${ }^{\mathrm{TM}}$ rapid plates (3M Company), according to the manufacturer's instructions.

The reading was performed with the assistance of a CP600 Plus (Phoenix ${ }^{\circledR}$ ) colony counter, in which the red colonies accompanied by gas bubbles were considered typical of TtC. Afterwards, the results were expressed in colony-forming-unit (CFU/g).

The colonies with typical characteristics of $\mathrm{TtC}$ were isolated using wire looping, coded and stored in brain heart infusion broth with $15 \%$ glycerol and kept at $-20{ }^{\circ} \mathrm{C}$, for posterior extraction of bacterial DNA, using the technique described by Silva et al. (2011).

In sequence, the polymerase chain reaction was performed in order to verify the following $E$. coli virulence genes: stx, typical of enterohaemorrhagic $E$. coli (EHEC), the $b f p A$ gene, typical of enteropathogenic E. coli (EPEC), and the genes elt and stl, both typical of enterotoxigenic E. coli (ETEC).

The amplification reactions were realized in an Amplitherm $^{\circledR}$ TX96 Plus thermocycler. The reagents and enzymes utilized for the gene amplification were: sterile milli-Q water, PCR buffer (10x) with magnesium chloride $\left(\mathrm{MgCl}_{2}\right)$ at $2 \mathrm{x}$ final concentration, deoxynucleotide triphosphate mixture (dNTPs $10 \mathrm{mmol} / \mathrm{L}$ ) at $0.2 \mathrm{mmol} / \mathrm{L}$ final concentration, primers (forward and reverse) at $0.8 \mathrm{pmol} / \mathrm{uL}$ final concentration each. Taq DNA polymerase at final concentration of $2 \mathrm{U}$ and DNA template $(3 \mathrm{uL})$. Final volume for each PCR reaction was $25 \mathrm{uL}$. As a positive control, an ATCC 11105 strain was utilized for the elt gene, an ATCC 43895 strain for the stx gene, a CDCO 111ab strain for the bfpA gene and an ATCC 11105 strain for the $s t$ gene. The byproducts were separated through $2 \%$ agarose gel electrophoresis, dyed with SYBR Green ${ }^{\circledR}$, using an Electrophoresis Power Supply EV $243^{\mathrm{TM}}$ - Consort.
Then, they were observed at the ultraviolet transilluminator Loccus L-PIX $\left(\mathrm{BDH}^{\circledR}\right)$. The PCR conditions, the primers sequences and the size of the amplified fragment for each observed gene are described on Table 1.

The study was approved by the UFRB Research Ethics Committee (CAAE 09931612.6.0000.0056), as determined by Resolution 466/2012 of the National Health Council (Brasil, 2012). Participants received explanations about the purpose of the research and gave their consent through the Informed Consent Form.

\section{Results and Discussion}

Out of the 65 analyzed samples, two samples from the queijadinha batch and one sample from the cassava cake batch presented colonies that are consistent with bacteria from the $\mathrm{TtC}$ group (Figure 1). Thus, three strains were isolated in order to perform the PCR. The genes used in these reactions were not identified in the isolated strains (Figure 2). It is suggested that the isolated strains are from $E$. coli with different virulence genes than the ones analyzed, or from another group of the $\mathrm{TtC}$, such as bacteria like Enterobacter or Klebsiella. However, for the elt and sti genes the positive controls were not amplified (data not shown). The probable causes for non-amplification of the positive controls genes are degradation of the primers used or, most likely, degradation of standard strain DNA to ETEC, or both.

The pathogenicity from E. coli pathotypes is dependent on virulence factors. These, in its turn, help the microorganism to settle and to cause damage to the host cells. The factors are encoded by virulence genes that can be detected by molecular methods such as PCR, as this method enables the amplification of characteristic genes for each pathotype (Moreira et al., 2018).

In determining the prevalence of diarrhogenic E. coli (DEC) in Peruvian children, Ochoa et al. (2011) described the genetic variability of isolated strains and observed a

Table 1. Conditions utilized in the Polymerase Chain Reaction for the detection of Escherichia coli genes associated to virulence.

\begin{tabular}{|c|c|c|c|}
\hline Gene/ serotype & Primer sequence (5' - 3') & (bp) & PCR's conditions \\
\hline stx / EHEC & $\begin{array}{l}\text { TTT ACG ATA GAC TTC TCG AC } \\
\text { CAC ATA TAA ATT ATT TCG CTC }\end{array}$ & 227 & $\begin{array}{l}5 \text { minutes at } 94^{\circ} \mathrm{C} / 35 \text { cycles at } 94{ }^{\circ} \mathrm{C} \\
\text { for } 1 \text { minute, } 3 \text { minutes at } 48{ }^{\circ} \mathrm{C} \text { and } \\
4 \text { minutes at } 72{ }^{\circ} \mathrm{C} / 10 \text { minutes at } 72^{\circ} \mathrm{C}\end{array}$ \\
\hline bfpA/EPEC & $\begin{array}{l}\text { AAT GGT GCT TGC GCT TGC TGC } \\
\text { GCC GCT TTA TCC AAC CTG GTA }\end{array}$ & 330 & $\begin{array}{l}5 \text { minutes at } 94{ }^{\circ} \mathrm{C} / 29 \text { cycles at } 94{ }^{\circ} \mathrm{C} \\
\text { for } 30 \text { seconds, } 1 \text { minute at } 56{ }^{\circ} \mathrm{C} \text { and } \\
2 \text { minutes at } 72{ }^{\circ} \mathrm{C} / 10 \text { minutes at } 72{ }^{\circ} \mathrm{C}\end{array}$ \\
\hline elt / ETEC & $\begin{array}{l}\text { GGC GAC AGA TTA TAC CGT GC } \\
\text { CCG AAT TCT GTT ATA TAT GTC }\end{array}$ & 696 & $\begin{array}{l}5 \text { minutes at } 94{ }^{\circ} \mathrm{C} / 30 \text { cycles at } 94{ }^{\circ} \mathrm{C} \\
\text { (desnaturation) for } 1 \text { minute, } 1 \text { minute } \\
\text { at } 56{ }^{\circ} \mathrm{C} \text { (annealing) and } 1 \text { minute } 72{ }^{\circ} \mathrm{C} \\
\text { (extension) } / 10 \text { minutes at } 72{ }^{\circ} \mathrm{C}\end{array}$ \\
\hline stI / ETEC & $\begin{array}{l}\text { TTA ATA GCA CCC GGT ACA AGC AGG } \\
\text { CTT GAC TCT TCA AAA GAG AAA ATT AC }\end{array}$ & 147 & $\begin{array}{l}5 \text { minutes at } 94{ }^{\circ} \mathrm{C} / 30 \text { cycles at } 94{ }^{\circ} \mathrm{C} \\
\text { for } 1 \text { minute, } 1 \text { minute at } 55^{\circ} \mathrm{C} \text { and } \\
1 \text { minute } 72{ }^{\circ} \mathrm{C} / 10 \text { minutes at } 72{ }^{\circ} \mathrm{C}\end{array}$ \\
\hline
\end{tabular}

(bp): Size of the amplified fragment in base pairs; PCR: Polymerase Chain Reaction. Source: Adapted from Silva et al. (2011). 
great variability of virulence genes for each pathotype. For example, it's been determined the presence and allelic variation for three virulence genes, eae, $b f p A$ and perA in 120 EPEC samples. These findings justify what may have occurred on this present study: even though each

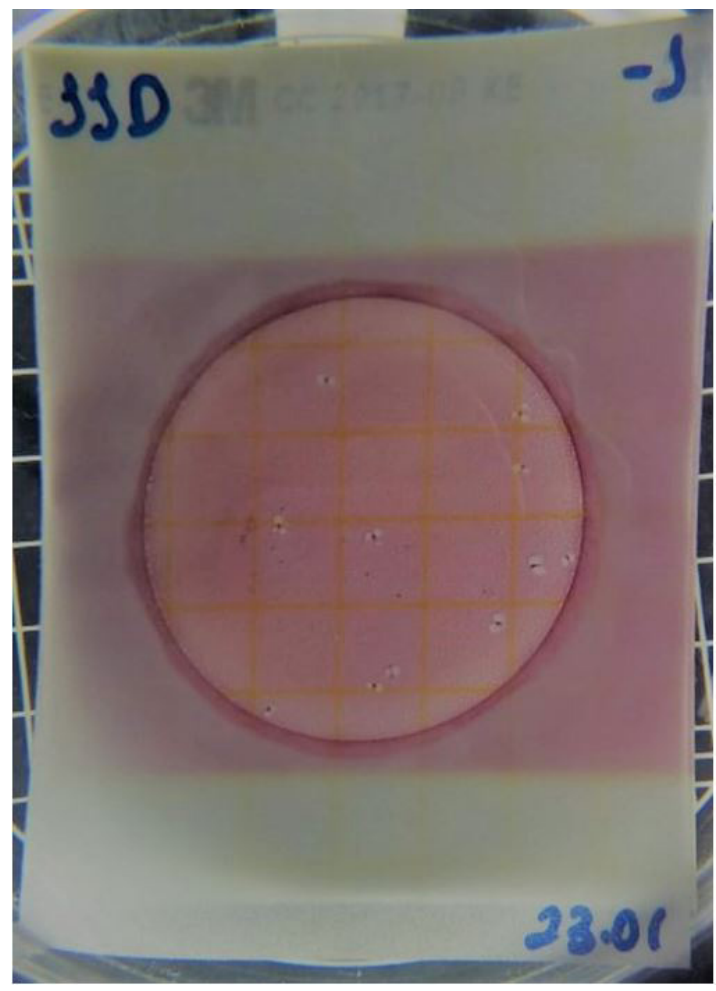

Figure 1. Photograph of Petrifilm ${ }^{\mathrm{TM}} \mathrm{CC}$ plate (3M Company) after incubation at $44.5^{\circ} \mathrm{C}$ showing characteristic colonies of thermotolerant coliforms from food (cassava cake) produced by local agribusinesses of a Solidarity Economic Venture of Valença, Bahia, Brazil. 2018. pathotype is characterized by a specific gene, it may still occur heterogeneity within the same group.

The result of this present study differs from the one performed by Cavalin et al. (2018), that aimed to identify the virulence genes eae, bfp, stx1, stx2, hlyA, ipaH, elt, est, aggR, aap and AA probe from the isolated E. coli strains in sausage samples produced and commercialized in the region of Londrina, Paraná State, Brazil. Forty-six samples were analyzed and one calabresa sausage (a type of spicy sausage) sample was contaminated with atypical enteropathogenic $E$ coli, from the serotype O108:H9, in which it was possible to identify the virulence genes eae and $h l y A$.

Similar results were presented in a study that aimed to investigate the occurrence of virulence genes (eagg, eaeA, stx1, stx2, ST, LT, rfb, O157 and ial) from E. coli strains isolated from raw milk commercialized at the south of Piauí State, Brazil. Fifty-two samples were analyzed and the genes eaeA and $L T$ were found at one sample, which characterized the analyzed milk as a carrier of virulent strains with potential to harm consumer's health (Fonsêca et al., 2017).

Since some strains of $E$. coli present a variety of genetic modifications (virulence genes) that increase their pathogenicity to humans and animals and that the ingestion of contaminated water and food with such strains may put consumer's health at risk, it is important to note that ventures that process food have full responsibility to assure the hygiene to all the production line, in order to keep the food free from any pathogenic agent or its toxins (Peter et al., 2016; Ávila et al., 2016).

The emergence of multi-resistant strains may occur as antimicrobials are increasingly used indiscriminately. Suboptimal concentrations of these antimicrobials are accidentally unintentionally but regularly dispensed through the environment, increasing the number of antimicrobial resistance genes (Mishra et al., 2018).

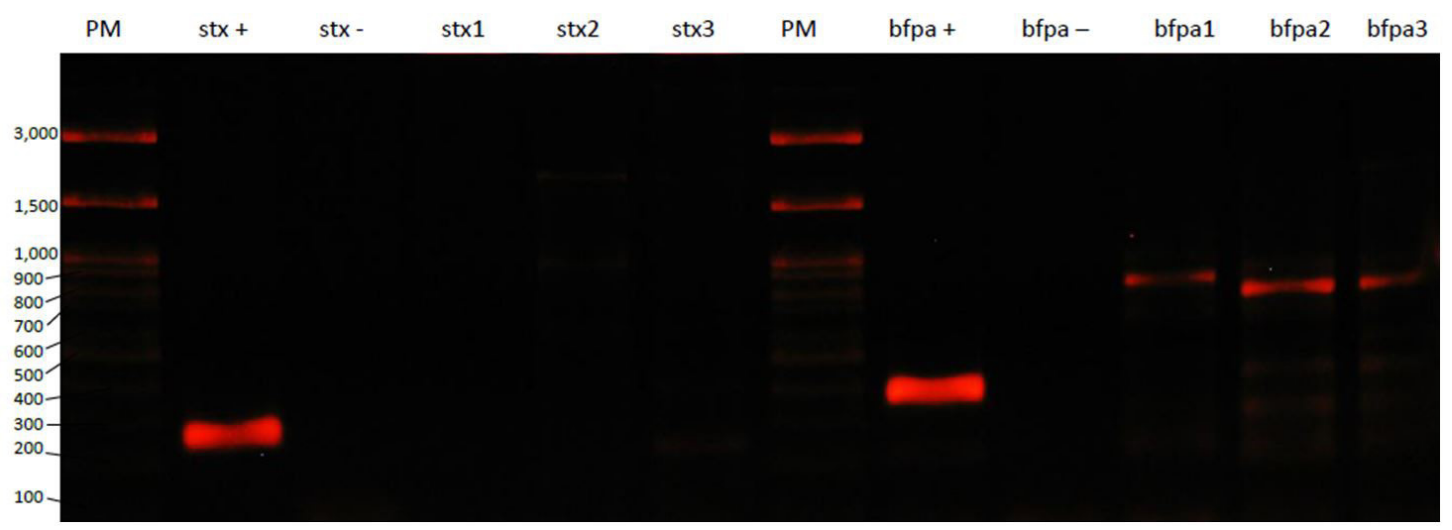

Figure 2. Photograph of 2\% Agarose Gel of Polymerase Chain Reaction for Escherichia coli stx (EHEC) and bfpa (EPEC) genes. $\mathbf{P M}=100$ pb DNA Ladder RTU; stx $+=$ positive control for the stx gene, ATCC 43895 strain; $\mathbf{b f p a}+=$ positive control for the bfpa gene, CDCO 111ab strain; stx- and bfpa- = negative control for stx and bfpa genes, respectively; stx1, 2, 3 and bfpa1, $\mathbf{2}, \mathbf{3}=E$. coli samples (Lab. Code - 3A, 3B and 11D, respectively). 
Even though the proposed E. coli virulence genes have not been confirmed, the detection of $\mathrm{TtC}$ on the analyzed food indicates hygiene flaws during the food manufacturing, therefore, measures to control and to prevent product contamination should be taken.

In addition, the presence of $\mathrm{TtC}$ in food may indicate faecal contamination, as demonstrated by Trmčić et al. (2016) which detected that the most E. coli isolated from cheese samples were of faecal origin.

To summarize it is recommended that the food processing ventures are aware of the principles of Good Manufacturing Practices. It is specially recommended that they use hygiene practices, which should be followed and maintained as a strategy to ensure that products are consistently produced and controlled according to quality standards and to prevent contamination by $\mathrm{TtC}$.

\section{Acknowledgements}

The authors thank the Bahia State Research Support Foundation (FAPESB - Fundação de Amparo à Pesquisa do Estado da Bahia) for granting the scholarship (TSC 0173/2018) and the Oswaldo Cruz Institute (Fiocruz) from Rio de Janeiro State, for the donations of the standard strains used as positive controls in the PCR reactions.

\section{References}

Á VILA, M.O., SANTOS, P.H.S., GOIS, F.N., FURTADO, M.C. and REIS, I.A.O., 2016. A importância do controle das condições microbiológicas e higiênico-sanitárias na prevenção de Doenças Transmitidas por Alimentos: Uma revisão de literatura. Revista Expressão Científica, vol. 1, no. 1, pp. 1-12.

BARBOSA, C.A., CONCEIÇÃO, T.A., BALIZA, M.D., CAMILO, V.M.A., JUIZ, P.J.L. and SILVA, I.M.M., 2019. Virulence genes in Escherichia coli isolates from commercialized saltwater mussels Mytella guyanensis (Lamarck. Brazilian Journal of Biology $=$ Revista Brasileira de Biologia, vol. 79, no. 4, pp. 625-628. http://dx.doi. org/10.1590/1519-6984.185930. PMid:30379238.

BELLA R.L.F., GOMES L.F.B., MESQUITAA.M., ARAÚJO E.A. and REGO R.B., 2018. Empreendimentos solidários: um estudo de caso do impacto econômico-social de uma cooperativa. Brazilian Journal of Development, vol. 4, no. 5, pp. 1651-1668.

CAVALIN, P.B.B., SARMIENTO, J.J.P., KOBAYASHI, R.K.T., NAKAZATO, G., OCAÑA, A.N. and OLIVEIRA, T.C.R.M., 2018. Pesquisa de Salmonella spp. e Escherichia coli diarreiogênica em linguiças suínas frescas. Semina: Ciências Agrárias, vol. 39, no. 4,pp. 1533-1546. http://dx.doi.org/10.5433/1679-0359.2018v39n4p1533.

Brasil. Conselho Nacional de Saúde, 2012. Resolução n ${ }^{\circ}$ 466, de 12 de dezembro de 2012. Aprova normas regulamentadoras de pesquisas envolvendo seres humanos [online]. Diário Oficial da República Federativa do Brasil, Brasília, 12 dez. Available from: https://bvsms. saude.gov.br/bvs/saudelegis/cns/2013/res0466_12_12_2012.html

FONSÊCA, M.F.C., MACHADO JÚNIOR, A.A.N., OLIVEIRA, M.S., CRUZ, R.L.P., CARDOSO, J.F., BATISTA, A.M.V. and PAULA, N.R.O., 2017. Genes de virulência eaeA e $L T$ em E. coli isoladas de leite cru comercializado no sul do estado do Piauí, Brasil. Revista Electrónica de Veterinaria, vol. 18, no. 9, pp. 1-9.
MACEDO, V.F., ZANARDO, J.G., LOPES, R.P.C., MENDONÇA, H.F.M.S., RAYMUNDO, N.L.S. and MORAES, R., 2016. Prevalência de coliformes e Staphylococcus aureus em mãos de manipuladores de alimentos de feira livre de Vitória, ES. Revista Salusvita, vol. 2, no. 2, pp. 27-38. http://dx.doi.org/10.5935/2447-7826.20160014.

MISHRA, M., ARUKHA, A.P., PATEL, A.K., BEHERA, N., MOHANTA, T.K. and YADAV, D., 2018. Multi-drug resistant coliform: water sanitary standards and health hazards. Frontiers in Pharmacology, vol. 9, pp. 1-8. http://dx.doi.org/10.3389/ fphar.2018.00311. PMid:29946253.

MOREIRA, B.S., AZOLA, J.S.M. and GOUVÊA, C.M.C.P. 2018. Marcadores moleculares para identificação e caracterização do potencial patogênico de Escherichia coli e Staphylococcus aureus. SaBios - Revista de Saúde e Biologia, vol. 13, no.1, pp.41-52.

ORGANIZAČ̃̃O DAS COOPERATIVAS BRASILEIRAS - OCB, 2019 [viewed 15 July 2019]. Anuário do Cooperativismo Brasileiro [online]. 121 p. Available from: file://C:/Users/Administrador/ Downloads/ANUARIO 2019 web.pdf

OCHOA, T.J., MERCADO, E.H., DURAND, D., RIVERA, F.P., MOSQUITO, S., CONTRERAS, C., RIVEROS, M., LLUQUE, A., BARLETTA, F., PRADA, A. and RUIZ, J., 2011. Frecuencia y patotipos de Escherichia coli diarrogénica em niños peruanos con y sin diarrea. Revista Peruana de Medicina Experimental y Salud Pública, vol. 28, no. 1, pp. 13-20. http://dx.doi.org/10.1590/S172646342011000100003. PMid:21537764.

PETER, C.M., PICOLI, T., PERES, A.F., CZERMAINSKI, L.A., RIPOLL, M.K., BRAGATO, M.S. and ZANI, J.L., 2016. Caracterização e sensibilidade de cepas de Escherichia coli isoladas do leite proveniente de tanques resfriadores de pequenas propriedades do município de Canguçu - RS. Science and Animal Health, vol. 4, no. 3, pp. 310-322. http://dx.doi.org/10.15210/sah.v4i3.8199.

POMBO, J.C.P., RIBEIRO, E.R., PINTO, R.L. and SILVA, B.J.M., 2018. Efeito antimicrobiano e sinergístico de óleos essenciais sobre bactérias contaminantes de alimentos. Segurança Alimentar e Nutricional, vol. 25, no. 2, pp. 108-117. http://dx.doi.org/10.20396/ san.v25i2.8651785.

RIBEIRO, K.A., 2017. Governança e educação cooperativista em cooperativas agropecuárias: o caso da CIVAB no município de Canudos (BA). Revista Brasileira de Assuntos Regionais e Urbanos, vol. 3, no. 2, pp. 284-304. http://dx.doi.org/10.18224/baru.v3i2.5941.

RODRIGUES, E.C.N., RIBEIRO, S.C.A. and SILVA, F.L. 2015. Não padronização de procedimentos operacionais em agroindústria familiar de polpa de frutas e seus efeitos na renda e satisfação dos associados. Revista do Observatorio de la Economía Latinoamericana, vol. 1, no. 211, pp. 1-19.

ROSA, J.L., BARROS, R.F. and SANTOS, M.O. 2016. Características da Escherichia coli enterohemorrágica (EHEC). Revista Acadêmica do Instituto de Ciências da Saúde - Saúde \& Ciência em ação, vol. 2, no. 1, pp. 66-78.

SILVA, I.M.M., EVÊNCIO-NETO, J., SILVA, R.M., LUCENASILVA, N., MAGALHÃES, J. and BALIZA, M., 2011. Caracterização genotípica dos isolados de Escherichia coli provenientes de frangos de corte. Arquivo Brasileiro de Medicina Veterinária e Zootecnia, vol. 63, no. 2, pp. 333-339. http://dx.doi.org/10.1590/S010209352011000200010 .

SILVA, R.S., MENDES, W., MAI, M.G., FOGAÇA, F.H.S., PEREIRA, A.M.L., MAGALHÃES, J.A. and COSTA, N.L. 2017. Caracterização do processamento artesanal da carne de caranguejo-uçá Ucides cordatus e perfil socioeconômico dos quebradores. Revista Pubvet, vol. 11, no. 6, pp. 566-574. 
SOUZA, C.O., MELO, T.R.B., MELO, C.S.B., MENEZES, E.M., CARVALHO, A.C. and MONTEIRO, L.C.R., 2016. Escherichia coli enteropatogênica: uma categoria diarreiogênica versátil. Revista Pan-Amazônica de Saúde, vol. 7, no. 2, pp. 79-91. http://dx.doi. org/10.5123/S2176-62232016000200010.

TRMČIĆ, A., CHAUHAN, K., KENT, D.J., RALYEA, R.D., MARTIN, N.H., BOOR, K.J. and WIEDMANN, M, 2016. Coliform detection in cheese is associated with specific cheese characteristics, but no association was found with pathogen detection. Journal of Dairy Science, vol. 99, no. 8, pp. 6105-6120. http://dx.doi.org/10.3168/ jds.2016-11112. PMid:27289158.

WORLD HEALTH ORGANIZATION - WHO, 2019 [viewed 15 July 2019]. Food Safety - Escherichia coli infections [online]. Available from: https://www.who.int/foodsafety/areas_work/ foodborne-diseases/ecoli/en/ 